\title{
Converging Recommendations for Culturally Responsive Literacy Practices: Students with Learning Disabilities, English Language Learners, and Socioculturally Diverse Learners
}

\author{
Susan V. Piazza \\ Western Michigan University \\ U.S.A. \\ Shaila Rao \\ Western Michigan University \\ U.S.A. \\ Maria Selena Protacio \\ Western Michigan University \\ U.S.A.
}

ABSTRACT: This study examines culturally responsive pedagogy across the fields of special education, multicultural literacy education, and teaching English language learners. A systematic review of recommendations identified culturally responsive practices in five key areas: dialogue, collaboration, visual representation, explicit instruction, and inquiry. Educators are encouraged to adopt a critical and responsive stance that incorporates students' cultural knowledge and lived experiences when implementing these recommendations. Creating classrooms that promote culturally responsive and effective instruction is grounded in the definition of literacy as a social practice and leads to more equitable learning opportunities in all areas.

KEYWORDS: multicultural education, culturally responsive literacy, multicultural literacy, special education, English language learner

Theoretical Perspectives

Methods

Discussion of Findings

Conclusion

References

Culturally responsive literacy practices are vital for the academic achievement of socioculturally diverse learners (Au, 2011; Gay, 2000, 2002; Ladson-Billings, 2011; Tatum, 2005) and learners with specific learning disabilities (LD) in inclusive settings (Gay, 2002; Klingner \& Edwards, 2006), as well as English Language Learners (ELLs) (Haynes, 2012; Villegas \& Lucas, 2007). Although research exists within each of the specialized areas of special 
education, multicultural literacy education, and ELLs, there is little published about the convergence of instructional practices across these three fields. The purpose of this article is to conduct a qualitative synthesis and overview of literature from each field that analyzes for converging language and literacy instructional practices. Three scholars from a Midwestern university collaborated to conduct a comparative analysis of scholarly articles from the fields of multicultural literacy education, special education, and teaching English as a second or other language. While this is not a comprehensive review of research, this analysis was systematic and targeted scholarly journals that inform U.S. educators in our respective fields of education. A sociocultural theoretical framework (Au, 2011; Luke, Woods, \& Dooley, 2011; Perry, 2012) informed the qualitative synthesis and review of articles. The convergence of instructional recommendations indicates there is growing consensus across the fields regarding promising instructional practices that will effectively support diverse learners.

\section{Theoretical Perspectives}

For the purposes of this review, we offer the following parameters in defining ELL, LD, and SDL. We define students with learning disabilities as those with a significant difficulty in language acquisition, listening, speaking, reading (word-recognition skills and comprehension), and writing. These difficulties are due to a disorder in the basic psychological processes such as memory, auditory and visual perception, oral language, and thinking (Learner \& Johns, 2015). We define ELLs as those who come from homes where English is not the primary language spoken and are in need of English language services. We define socioculturally diverse students as individuals who have been traditionally marginalized because of social factors such as race, ethnicity, gender, and poverty. In choosing a theoretical framework for this literature review, we focus on sociocultural theory and culturally responsive literacy practices. All learners are unique, and it is important to note that diverse learners will have overlapping features that exist within and across each of the categories in this analysis. It is precisely the many overlaps from which this comparative analysis of instructional practices across the three fields emerged.

\section{Sociocultural Theory}

Sociocultural theoretical perspectives in the field of literacy (Au, 2011; Lewis, Enciso, \& Moje, 2007; Luke, Woods, \& Dooley, 2011; Vygotsky, 1978) were used to examine the recommended practices that support responsive pedagogy across three fields. We found Perry's (2012) overview of sociocultural perspectives especially relevant in this process as it provided three frames of reference within sociocultural theory: (a) literacy as social practice, (b) 
multiliteracies, and (c) critical literacy. First, literacy as a social practice is often attributed to Vygotsky (1978), who posited that all human interactions are mediated by language and symbols and are heavily influenced by social, cultural, and historical contexts. Second, there are also multiple literacy perspectives that take us beyond print or written text to include modes of meaning such as visual, audio, and spatial patterns of meaning (Cope \& Kalantzis, 2009). A third perspective includes critical literacy, which acknowledges individual learners' power and sense of agency as they learn about the world through words in print, or through multimodal communication around them (Freire, 2000). These views contextualize literacy development as situated in various sociocultural contexts and promise more equitable learning for diverse students. Equity is relevant to the discussion of responsive literacy instruction because when skills are delivered to students in a proposed context-free environment, diverse learners become marginalized when their home literacy practices are socioculturally different from what is considered normative.

\section{Culturally Responsive Literacy Pedagogy}

As we identified convergence across three fields, we drew upon the framework of culturally responsive teaching (CRT), which is defined as "using the cultural knowledge, prior experiences, frames of reference, and performance styles of ethnically diverse students to make learning encounters more relevant to and effective for them" (Gay, 2010, p. 31). It requires that students' strengths rather than weaknesses are a starting point for instruction. U.S. classrooms are increasingly complex spaces in which readers become literate, comprehend multiple kinds of texts, and adapt knowledge of the world, through the lenses of their lived experiences (Ladson-Billings, 2011; Lankshear, 1997; Lipson \& Wixson, 2013). CRT is prevalent across all three fields and is well-documented in the literature as being vital to students' learning (Au, 2011; Banks \& Banks, 2004; Cartledge \& Kourea, 2008; Gay, 2002; Goldenberg, 2013; Klingner \& Edwards, 2006; Ladson-Billings, 2011; Mercer, Mercer, \& Pullen, 2011; Street, 2012). CRT is a stance that must be adopted by teachers in order to effectively and consistently increase student achievement through socially, culturally, and linguistically responsive instruction. Once a CRT stance is embraced, all other promising practices become more likely to be effective for diverse learners.

It is critical that all students be given the opportunity to connect their own worlds of language and communication to the curriculum they encounter in schools. An additional area of concern within CRT is the importance of multiple teaching materials and resources that connect to students' everyday lived experiences (Comber, 2013; Guerra, 2012; Hall \& Piazza, 2010; Medina, 2010; Street, 2012; Tatum, 2005). It is important to note that the selection of materials alone is never sufficient, but its importance must not be overlooked (Tatum, 2005). Formal and informal literacies, just as in-school and out-of-school literacies, are contextualized and situated in the social and cultural practices in all 
settings. The definition of text has expanded to include things such as websites, videos, student writing, public speech, applications [apps], advertising, music, and art. This expanded definition of text ensures that educators are responsive not only to diverse learners, but also to the changing world we live in.

\section{Methods}

Cooper's (2010) taxonomy of literature reviews guided this qualitative synthesis of instructional practice across three fields. There are six characteristics of literature reviews provided by Cooper, and the following is how we address each area:

1. The focus of the review aims to identify instructional practices that are valued and promoted across three fields of interest;

2. The goal of the review is to identify and build linguistic bridges across three fields so that even when different terminology or practice is promoted, we may recognize a convergence in overall approach;

3. The perspective of the review is grounded in sociocultural and critical theories of education;

4. The coverage of literature reviewed was determined to be a representative sample in the form of 10 articles from each field;

5. The organizational approach is considered conceptual in nature as it targets recommended practices for specific and diverse student populations; and

6. The audience for this review is general education scholars, policy makers, and practitioners.

Some argue there is little evidence that documents culturally responsive teaching for culturally, linguistically, and cognitively diverse learners (e.g., August \& Shanahan, 2006). However, there are scholarly articles that provide valuable insights to instructional practices that support improved student outcomes when educators attend to students' identities, cultural and linguistic backgrounds, and out-of-school literacies (Anderson \& Sadler, 2009; Mclntyre \& Hulan, 2013; Piazza, 2011). The controversy is due in part to the narrow scope of studies included in many literature reviews that limit themselves to experimental designs and randomized trials. This descriptive review of literature will identify converging discourses and practices within and across three fields of education, which might then lead to such systematic reviews. For example, the National Reading Panel (2000) shaped major policies and dialogue around effective literacy instruction based on a limited review of studies, which was not preceded or followed by descriptive studies such as these. As qualitative researchers, this review will provide insights into evidence that may then support the further study of convergence across other fields regarding culturally responsive literacy 
instruction and diverse learners. The following sections provide the review process employed in conducting this study of literature across three fields.

\section{Literature Review Process}

The researchers read widely and met three different times to narrow selection criteria. The first round of reviews focused on peer reviewed literature promoting promising practices for special education students, socioculturally diverse learners, and English language learners. The second round of reviews focused on targeting scholarly databases such as ERIC, Education Abstracts, Google Scholar, JSTOR Arts and Sciences 6, ProQuest Research Library, among others. Search terms included effective literacy instruction, responsive pedagogy, literacy, reading, writing, reading difficulty, and literacy terms such as vocabulary, comprehension, and fluency. For a more focused attempt, terms related to each of the three fields were added, such as learning disability, special education, reading disability, English-language learners, second language learners, English as a second language, culturally responsive literacy instruction, and culturally relevant teaching. The third round of reviews resulted in the identification of the following criteria for selecting the representative sample of articles to be included in this qualitative synthesis of practices:

- Articles must be published in peer reviewed scholarly journals.

- Publication dates must be $\mathbf{2 0 0 0}$ or later in an effort to focus on current trends.

- Articles must rely upon qualitative or quantitative research as a basis for the recommended practices.

- Articles must specifically address literacy practices that are responsive to culture or language.

- Articles must address literacy practices that have demonstrated improved academic outcomes in reading and/or literacy processes.

\section{Analysis}

Once the 10 articles from each field were selected, researchers conducted a comparative thematic analysis (Creswell, 2009) to identify converging instructional recommendations. The comparative thematic analysis included the following steps:

1. Many instructional themes were identified in efforts to generate initial categories for effective practices;

2. Similarities between and within those themes led to the development of a thematic coding system; 
3. The process became iterative through the search for themes, defining and redefining themes, organizing them into a database, and making final revisions to thematic categories.

These research methods resulted in an analytic framework consisting of five instructional recommendations, which represent a review of converging recommended instructional practices for students with learning disabilities, students who are English-language learners, and students from diverse social and cultural backgrounds. The 30 articles reviewed in this study converge around the following five themes and are presented in Table 1 below: dialogue, collaboration, visual representation, explicit instruction, and inquiry.

\section{Table 1}

Converging Recommendations for Culturally Responsive Literacy Practices

\begin{tabular}{|c|c|c|c|c|c|}
\hline Articles Reviewed & Dialogue & $\begin{array}{l}\text { Collabo- } \\
\text { ration }\end{array}$ & $\begin{array}{l}\text { Visual } \\
\text { Represen- } \\
\text { tation } \\
\end{array}$ & $\begin{array}{l}\text { Explicit } \\
\text { Instruction }\end{array}$ & Inquiry \\
\hline \multicolumn{6}{|c|}{ Students with Learning Disabilities } \\
\hline $\begin{array}{l}\text { Anderson \& Corbett } \\
(2008)[+E L L+S D L]\end{array}$ & $\diamond$ & $\diamond$ & $\diamond$ & & $\diamond$ \\
\hline Apthorp (2006) [+ELL] & $\diamond$ & $\diamond$ & & $\diamond$ & \\
\hline Cowden ( 2012) & $\diamond$ & $\diamond$ & & $\diamond$ & \\
\hline Coyne et al. (2010) & $\diamond$ & $\diamond$ & & $\diamond$ & \\
\hline Dorr (2006) [+ELL+SDL] & $\diamond$ & $\diamond$ & $\diamond$ & & $\diamond$ \\
\hline $\begin{array}{l}\text { Kim et al. (2006) } \\
\text { [+ELL+SDL] }\end{array}$ & $\diamond$ & $\diamond$ & $\diamond$ & $\diamond$ & $\diamond$ \\
\hline $\begin{array}{l}\text { Mahdavi \& Tensfeldt } \\
\text { (2013) [+ELL+SDL] }\end{array}$ & & & $\diamond$ & & $\diamond$ \\
\hline Menzies et al. (2008) & $\diamond$ & $\diamond$ & & $\diamond$ & \\
\hline $\begin{array}{l}\text { Narkon \& Wells (2013) } \\
\text { [+ELL+SDL] }\end{array}$ & $\diamond$ & $\diamond$ & $\diamond$ & & $\diamond$ \\
\hline Roberts et al. (2008) & $\diamond$ & $\diamond$ & $\diamond$ & $\diamond$ & \\
\hline \multicolumn{6}{|c|}{ English Language Learners } \\
\hline $\begin{array}{l}\text { Barr, Eslami, \& Joshi } \\
\text { (2012) }\end{array}$ & & & & $\diamond$ & \\
\hline $\begin{array}{l}\text { Calderon et al. (2011) } \\
\text { [+SDL] }\end{array}$ & & $\diamond$ & & $\diamond$ & \\
\hline
\end{tabular}




\begin{tabular}{|c|c|c|c|c|c|}
\hline $\begin{array}{l}\text { Facella et al. (2005) } \\
\text { [+SDL] }\end{array}$ & $\diamond$ & $\diamond$ & $\diamond$ & $\diamond$ & \\
\hline Francis et al. (2006) & $\diamond$ & & & $\diamond$ & \\
\hline $\begin{array}{l}\text { Genesee et al. (2005) } \\
\text { [+SDL] }\end{array}$ & $\diamond$ & $\diamond$ & & $\diamond$ & $\diamond$ \\
\hline Gersten et al. (2007) & & $\diamond$ & & $\diamond$ & \\
\hline Goldenberg (2013) & $\diamond$ & & $\diamond$ & $\diamond$ & \\
\hline $\begin{array}{l}\text { Hansen-Thomas (2010) } \\
\text { [+SDL] }\end{array}$ & & $\diamond$ & & $\diamond$ & $\diamond$ \\
\hline O’Day (2009) [+SDL] & $\diamond$ & & & & \\
\hline Saunders et al. (2013) & $\diamond$ & $\diamond$ & & $\diamond$ & \\
\hline \multicolumn{6}{|c|}{ Socioculturally Diverse Learners } \\
\hline $\begin{array}{l}\text { Castagno \& Brayboy } \\
\text { (2008) [+ELL] }\end{array}$ & $\diamond$ & $\diamond$ & $\diamond$ & $\diamond$ & \\
\hline Comber (2013) [+ELL] & $\diamond$ & & $\diamond$ & & $\diamond$ \\
\hline $\begin{array}{l}\text { Greenleaf \& Hinchman } \\
\text { (2009) }\end{array}$ & & $\diamond$ & & $\diamond$ & $\diamond$ \\
\hline $\begin{array}{l}\text { Hansfield \&Jiménez } \\
\text { (2009) [+ELL] }\end{array}$ & $\diamond$ & & $\diamond$ & $\diamond$ & \\
\hline $\begin{array}{l}\text { Ivey \& Broaddus (2007) } \\
\text { [+LD] }\end{array}$ & $\diamond$ & $\diamond$ & $\diamond$ & $\diamond$ & 0 \\
\hline $\begin{array}{l}\text { Mclntyre \& Hulan (2013) } \\
\text { [+ELL] }\end{array}$ & $\diamond$ & $\diamond$ & & $\diamond$ & \\
\hline Medina (2010) [+ELL] & $\diamond$ & $\diamond$ & $\diamond$ & & \\
\hline Peck (2010) & & $\diamond$ & & $\diamond$ & $\diamond$ \\
\hline Tierney (2009) & & $\diamond$ & $\diamond$ & & \\
\hline Wohlwend (2008) & $\diamond$ & $\diamond$ & $\diamond$ & $\diamond$ & \\
\hline
\end{tabular}

Note. Articles that address socioculturally diverse learners are coded [+SDL], learning disability [+LD], and English language learners [+ELL]. 


\section{Discussion of Findings}

In this section, each instructional approach will be operationally defined, grounded in the research and supporting theory, and linked to implications for use in classrooms to support diverse learners from all backgrounds.

\section{Dialogue}

The definition of dialogue can be traced back to sociocultural theories of literacy as it provides opportunities for learners to use language as a tool to mediate actions and interactions (Bakhtin, 1986; Vygotsky, 1978). Language and communication are rooted in the material and social worlds of diverse learners (Gee, 2001). Recommendations for the use of dialogue were found in 22 of the 30 articles reviewed and represent critical pedagogical practices for diverse learners due to its strong research base and theoretical underpinnings (Anderson \& Corbett, 2008; Goldenberg, 2013; Mclntyre \& Hulan, 2013; Medina, 2010; Sperling, Appleman, Gilyard, \& Freedman, 2011). When students engage in dialogue, particularly around texts and life experiences, they use new language, connect the known to unknown, and expand their worldviews (Comber, 2013; Medina, 2010). The National Literacy Panel on Language-Minority Youth and Children prepared by August and Shanahan (2006) found that oral proficiency in English is critical to developing ELLs' literacy skills, but it is often not explicitly addressed in classrooms, despite evidence of its positive effect on learning.

We divided the use of dialogue in effective and culturally responsive ways into two approaches. The first approach addresses dialogic interactions between teachers and students. Teachers should engage students with instructional goals in order to encourage deep and active processing of words and meanings. During extended talk, teachers pose cognitively challenging questions to activate higher order thinking and prompt effective vocabulary growth and reading comprehension (Apthorp, 2006; Ivey \& Broaddus, 2007; Kim et al., 2006). Strategies that are based on these recommendations are cited as collaborative strategic reading (CSR) (Kim et al., 2006); instructional conversations (Goldenberg, 2013), cognitive strategy instruction (Hansfield \& Jiménez, 2009); language experience approach (LEA) (Dorr, 2006); and direct and extended vocabulary instruction (Coyne et al., 2010). Such practices encourage students to process text and ideas for deeper levels of understanding, which improves comprehension, critical thinking, and overall achievement.

The second approach addresses dialogue between peers and is an important opportunity for ELLs, students with learning disabilities, and socioculturally diverse learners to reflect on ideas and engage with their peers (Apthorp, 2006; Coyne et al., 2010; Ivey \& Broaddus, 2007; Medina, 2010; Wohlwend, 2008). Recommended practices include collaborative reading 
strategies (CSR) (Kim et al., 2006), literature circles (Medina, 2010), reciprocal teaching (Hansfield \& Jiménez, 2009), peer-tutoring, book discussions, learning together through inquiry and questioning (Hansen-Thomas \& Cavagnetto, 2010; Ivey \& Broaddus, 2007; Mahdavi \& Tensfeldt, 2013), and peer assisted learning strategies (PALS) (Mahdavi \& Tensfeldt, 2013). Dialogue that centers on texts, ideas, and issues provides classroom opportunities for learners to experience others' thoughts, which allows for deliberation and critical reflection about their own and others' perspectives. In these conversations students extend their understandings of texts and mentor each other in ways that will improve comprehension, vocabulary, and critical thinking (Anderson \& Corbett, 2008; Castagno \& Brayboy, 2008; Medina, 2010; Roberts, Torgesen, Boardman, \& Scammacca, 2008; Saunders, Goldenberg, \& Marcelletti, 2013).

\section{Collaboration}

Literacy as a social practice emphasizes that learners construct meaning through social interactions, which allows them to exchange ideas and learn alongside of more knowledgeable or experienced others (Vygotsky, 1978). In sociocultural theory, the interactions with a knowledgeable other are understood to create a critical learning opportunity known as the zone of proximal development (ZPD). More experienced partners, who could be adults or peers, provide scaffolding (Turnbull, Turnbull, Wehmeyer, \& Shogren, 2013). Gargiulo and Metcalf (2013) viewed collaboration in educational settings as a cooperative relationship between two or more individuals working toward a mutually agreed upon goal. Research in the field of new literacies adds to this definition in that there is increasing value being placed on cooperation and collaboration when students build their understandings and create knowledge online and use multimedia. These recommendations shift instructional emphasis to highlight process and participation rather than traditional authorship, products, and individual ownership (Lankshear \& Knobel, 2007).

Collaboration was recommended in 23 of the 30 articles reviewed across three fields. Evidence-based strategies for teaching reading in all three areas highlighted grouping structures to promote collaboration. In teaching reading and writing to students with learning disabilities (LD) and students who are English language learners (ELLs), large group instruction, small group instruction, and peer partners are instructional arrangements recommended to maximize learning potential (Anderson \& Corbett, 2008; Apthorp, 2006; Barr, Eslami, \& Joshi, 2012; Calderon, Slavin, \& Sanchez, 2011; Coyne et al., 2010; Dorr, 2006; Facella, Rampino, \& Shea, 2005; Gersten et al., 2007; Genesee, Lindholm-Leary, Saunders, \& Christian, 2005; Kim et al., 2006; Mahdavi \& Tensfeldt, 2013; Saunders et al., 2013). These studies explored various forms of grouping structures that enable teachers to increase instructional time and provide students opportunities to actively respond. Additional recommendations include peer mediated learning such as PALS and Class-wide Peer Tutoring (CWPT), 
which are used with pairs or small groups and roles of tutee and tutor are often changed (Mahdavi \& Tensfeldt, 2013).

Collaborative learning and group discussions are often recommended simultaneously (Apthorp, 2006; Comber, 2013; Cowden, 2012; Dorr, 2006; Hansen-Thomas \& Cavagnetto, 2010; Menzies, Mahdavi, \& Lewis, 2008; Roberts et al. 2008). Students struggling to read and comprehend due to learning disabilities or due to their limited English proficiency benefit from working with knowledgeable others, learning specific strategies for new vocabulary, comprehension, and fluency. Dorr (2006) recommends the language experience approach (LEA) as a valuable tool for accessing and developing prior knowledge before moving on to a new topic. LEA emphasizes a connection between context, thinking, speaking, listening, viewing, writing, and reading and provides a balanced approach that connects all aspects of literacy instruction that will benefit all students whether they are language learners, identified with SDL, or socioculturally diverse.

\section{Visual Representation}

Eilam (2012) states that visual representations (VR) like charts, graphs, maps, artworks, and photographs form an inherent part of the cognitive, cultural, and social aspects of learning for both students and teachers. Research cautions that in contemporary classrooms the student population is becoming increasingly diverse and this calls for culturally responsive visual representations (Castagno \& Brayboy, 2013; Eilam, 2012). One of several recommended questions for teachers to reflect on is, "When and how should visual representations be generated for promoting understanding among particular students?" (Eilam, 2012, p. 9).

Treating visual forms of literacy and communication as social practices, Street (2012) highlights the importance of multimodal literacies, or new literacies, and reiterates that these forms of information and/or ways of communicating help create and influence our relationships and environments. The use of visual representation can be particularly helpful for ELLs who may have the conceptual knowledge but not the linguistic knowledge to fully understand texts (Goldenberg, 2013; Goldenberg, Hicks, \& Lit, 2013). Visual representations are helpful resources that facilitate ELLs' and many diverse learners' comprehension of content.

The converging recommendations for visual information were found in 15 of the 30 articles reviewed across three fields. Several studies (Anderson \& Corbett, 2008; Apthorp, 2006; Comber, 2013; Dorr, 2006; Facella et al., 2005; Goldenberg, 2013; Goldenberg, Hicks, \& Lit, 2013; Kim et al., 2006; Mahdavi \& Tensfeldt, 2013; Narkon \& Wells, 2013; Vaughn \& Edmonds, 2006) used Venn diagrams, diagrams with explicit teaching of concepts, timelines, sketches, flowcharts, story maps, sentence strips, graphic organizers, visuals, models, 
drawings, diagrams, tables, pictures, realia, charts, and semantic and concept maps to represent reading material visually for students with learning disabilities, ELLs, and students from diverse cultural backgrounds to better comprehend text. Technology enhanced concept maps can be generated using software programs such as Kidspiration and Inspiration software. Universal design for learning or UDL-enhanced story mapping was used to improve reading comprehension by Narkon and Wells (2013).

In addition to accessing content through visual images, students should be offered multiple ways to represent their understandings through images. Examples are the use of graphic representations, models, drawings, diagrams, tables, pictures, realia, and many of the same online visual tools mentioned previously. For example, Wohlwend (2008) documented students' negotiation of their understandings of books and film through drawings, performances, and play. Ivey and Broaddus (2007) document the effective use of think-alouds that use visuals and gestures to support comprehension of English vocabulary. Medina (2010) shared the powerful learning experiences of elementary immigrant children who visually mapped their physical movements across places, time, and cultures, which he referred to as "cultural flows" (p. 40). Most content lends itself to authentic engagements with visual information, both during instruction to share information and in providing students with multiple means of representation.

\section{Explicit Instruction}

We utilize Archer and Hughes' (2011) definition of explicit instruction as "a structured, systematic, and effective methodology for teaching academic skills" (p. 1). While explicit instruction may sometimes be used interchangeably with direct instruction, we emphasize that we do not mean direct instruction. In their recommendation for using explicit instruction with dual-language learners, Saunders et al. (2013) make a distinction between direct instruction and explicit instruction. Unlike direct instruction, explicit instruction can be inductive. In other words, explicit instruction can be carried out in ways that allow students to acquire new skills in addition to thinking deeply and participating in social situations to think critically about issues and content (Delpit, 1995; Mclntyre \& Hulan, 2013). Explicit instruction was the area which appeared most frequently out of all five instructional practices; it was recommended in 22 of the 30 articles reviewed in this study.

Explicit instruction can occur in several ways. For instance, teachers who use explicit instruction provide verbal, written and/or visual instructions that are concise and clear (e.g., Goldenberg, 2013; Roberts et al., 2008). Next, teachers use the gradual release of responsibility model (Pearson \& Gallagher, 1983) to initially provide students with explicit instruction through teacher modeling (Barr et al., 2012; Comber, 2013; Monroe \& Troia, 2006; Narkon \& Wells, 2013; Patel \& Laud, 2009). Overwhelmingly though, the majority of studies connected explicit 
instruction in with vocabulary instruction (Barr et al., 2012; Calderon et al., 2011; Coyne et al., 2010; Facella et al., 2005; Francis, Rivera, Lesaux, Kieffer, \& Rivera; 2006; Gersten et al., 2007; Goldenberg; 2013; Greenleaf \& Hinchman, 2009; Mclntyre \& Hulan, 2013; Roberts et al., 2008). Effective and explicit vocabulary instruction includes exposure to target words over several days (through reading, writing, and speaking opportunities) with the goal being students' rich understanding so they can use these words in their productive vocabulary (Gersten et al., 2007). As well, Roberts et al. (2008) emphasized the use of explicit instruction focusing on simple definitions, examples, and nonexamples while learning new and challenging vocabulary encountered in content related texts. In another example, Dorr (2006) described a language experience approach lesson in science where the language goal was to use students' background word knowledge and connect it to academic vocabulary. The lesson involved explicit literacy instruction wherein children's previously acquired knowledge on the topic of fruits and vegetables were linked to facts and concepts in their science unit on plants.

Several of the articles caution educators that even though explicit instruction in the basics is often recommended in the research for diverse learners, long-term reading achievement is most influenced by rich language experiences, critical thinking skills, and making connections to texts (Anderson \& Sadler, 2009; Comber, 2013; Ivey \& Broaddus, 2007). Thus, it is apt that the final theme we identified is the importance of inquiry-based learning to promote critical and collaborative reading and writing opportunities for diverse learners.

\section{Inquiry}

A widely held definition of inquiry in the field of literacy is a process in which learners generate questions within an area of interest or within a specific content area, investigate to find information, record new information, and make sense of their learning through the use of collaboration and multiple sign systems (Comber, 2013; Harste \& Burke, 2014; Lewison, Leland \& Harste, 2014; Short, 1996). Constructivist approaches to learning emphasize the social nature of dialogue, collaboration, use of multiple media, and questioning to motivate learners as an effective practice.

Challenging theme-based curricula results in increased motivation and engagement for diverse learners wherein students benefit from engaged, handson collaborative activities (Comber, 2013; Freedman \& Carver, 2007; Greenleaf \& Hinchman, 2009; Ivey \& Broaddus, 2007; Wohlwend, 2008). Research documents that when learners of all ages and backgrounds interact with realworld information to make connections and raise critical questions, they are motivated to inquire and learn about important topics and social issues (Comber, 2013; Hansen-Thomas \& Cavagnetto, 2010; Mclntyre \& Hulan, 2013; Medina, 2010; Narkon \& Wells, 2013). Inquiry based learning showed up across all three fields as a recommended practice; however, this was the area where the least 
amount of evidence was found. Only 11 of the 30 articles reviewed for this study talked about inquiry as evidence based practice for diverse learners. We suggest that one possible reason for this may be deficit perspectives that position students with learning disabilities, ELLs, and socioculturally diverse learners as less capable of working independently or collaboratively on inquiry processes. Another might be the overarching nature of inquiry, thematic learning, and project based learning, which includes all four of the other instructional themes found in this study.

Inquiry based learning requires students to generate questions and seek out information (Comber, 2013; Greenleaf \& Hinchman, 2009). Inquiry and writing are central to this approach and provide a way to examine writing movement "toward critical social thought" (Gutiérrez, 2008, p. 149). As well, this approach links to sociocultural theory with regard to supporting critical literacy that encourages students to question texts, dig deeper, and challenge the status quo (Comber, 2013; Freire, 2000). This is the complementary nature of inquiry to the use of explicit instruction. Together, these instructional approaches support diverse learners' skills, knowledge, and critical thinking related to issues in their community and broader lives in order to more fully participate in democratic societies.

\section{Conclusion}

Schools have struggled to serve students from diverse backgrounds, and there is an ongoing achievement gap noted between students by race, class, and gender (Au, 2011; Greenleaf \& Hinchman, 2009). Black students and students living in poverty are overrepresented in special education services (Fiedler et al., 2008). The National Center for Education Statistics (NCES, 2011) noted that almost half of the students in the United States are non-White, yet the majority of teachers are White and come from middle or upper-class backgrounds. Teachers overwhelmingly report they do not feel prepared with the knowledge or experience to effectively address the learning needs of students from socially, culturally, and linguistically diverse backgrounds (e.g., Gandara, Maxwell-Jolly, \& Drisoll, 2005; Hansen-Thomas \& Cavagnetto, 2010; Rubinstein-Avila \& Johnson, 2008). The challenge then becomes increasing the knowledge and cultural responsiveness of educators in order to implement curriculum and instruction that meets the specific needs of diverse learners.

This is by no means an exhaustive review of research. However, the findings do highlight what we have systematically found to be converging recommended instructional practices promoting equitable and culturally responsive literacy instruction for all students. It was our intention to uncover convergence across three fields to build bridges for shared language and collaboration. At first glance, the instructional practices identified in this paper seem to be simply practices of effective instruction in general. Indeed, these are effective practices for all populations, but we caution, along with Goldenberg 
(2013), that simply using these practices is insufficient "to promote accelerated learning" (p. 5). Teachers cannot rely on simply using practices when attempting to create meaningful learning experiences for diverse student populations. Teachers will need to adopt a critical and culturally responsive stance, along with understanding how to modify these instructional recommendations to be effective across various student populations.

In recommending the adoption of a culturally responsive stance, we return to Gay's (2010) definition which explains that when students' cultural knowledge, prior experiences, frames of reference, and performance styles influence our everyday instruction and the selection of learning materials, we are responding more effectively to learners' needs. The five instructional practices outlined in our review of scholarly articles incorporate opportunities for teachers to make adaptations for learner differences. Creating classrooms that promote dialogue and collaboration between students is highly recommended across all three fields as it embodies the notion of literacy as a social practice. Through collaborative conversations, students extend their understandings of texts and mentor each other in ways that will improve comprehension, vocabulary, and critical thinking. The use of visual representations for delivering content as well as multimedia representations of student understandings acknowledges different ways of knowing and encourages students to bridge their home and community literacy practices with school expectations. Explicit instruction provides the assurance that diverse learners are receiving quality instruction that provides them access to all of the necessary information, content, and skills needed to succeed in workplaces and in schools with standard expectations. The discussion of explicit instruction has been argued from the perspective that language and literacy skills provide access to power; therefore, if students are not explicitly taught what is needed to access power, they are not receiving fair and equitable educational opportunities. Finally, inquiry-based learning is a complementary approach to explicit instruction and provides the contextualized and content-based learning that students find motivating and engaging.

Imagine what schools would be like if all educators had the knowledge and experience to create challenging learning experiences and set high expectations for every learner. Imagine if the notion of culturally responsive pedagogy became redundant because standardized curriculum and instruction no longer influenced practice, but instead learners' strengths and diverse life experiences were at the center of instructional planning and use of resources. These recommendations offer educators the opportunity to begin truly closing achievement gaps and working against the overrepresentation of minority and underrepresented populations in special education, to serve English language learners more effectively, and to support teachers in their efforts to become more adept with culturally responsive practices. 


\section{References}

Anderson, P. L., \& Corbett, L. (2008). Literature circles for students with learning disabilities. Intervention in School and Clinic, 44(1), 25-33.

Anderson, K. A., \& Sadler, C. I. (2009). The effects of school-based curricula on reading achievement of African American males in special education. The Journal of Negro Education, 78(3), 333-46.

Apthorp, H. S. (2006). Effects of supplemental vocabulary program in third-grade reading/ language arts. The Journal of Educational Research, 100(2), 6779.

Archer, A. L., \& Hughes, C. A. (2011). Explicit instruction: Effective and efficient teaching. New York, NY: Guilford Press.

$\mathrm{Au}, \mathrm{K} . \mathrm{H}$. (2011). Literacy achievement and diversity: Keys to success for students, teachers, and schools. New York, NY: Teachers College Press.

August, D., \& Shanahan, T. (Eds.). (2006). Developing literacy in secondlanguage learners: Report of the National Literacy Panel on Language Minority Children and Youth. Mahwah, NJ: Lawrence Erlbaum.

Bakhtin, M. M. (1986). Speech genres and other late essays. Translated by V. McGee. Austin, TX: University of Texas Press.

Banks, J. A., \& Banks, C. A. M. (Eds.). (2004). Handbook of Research on Multicultural Education (2nd ed.). San Francisco, CA: Jossey-Bass.

Barr, S., Eslami, Z. R., \& Joshi, R. M. (2012). Core strategies to support English language learners. The Educational Forum, 76(1), 105-117. doi:10.1080/00131725.2012.628196

Calderon, M., Slavin, R., \& Sanchez, M. (2011). Effective instruction for English learners. The Future of Children, 21(1), 103-127.

Cartledge, G., \& Kourea, L. (2008). Culturally responsive classrooms for culturally diverse students with and at risk for disabilities. Exceptional Children, 74(3), 351-71.

Castagno, A. E., \& Brayboy, B.M.J. (2008). Culturally responsive schooling for indigenous youth: A review of the literature. Review of Educational Research, 78(4), 941-93.

Comber, B. (2013). Schools as meeting places: Critical and inclusive literacies in changing local environments. Language Arts, 90(5), 361-71.

Cope, B., \& Kalantzis, M. (2009). Multiliteracies: New literacies, new learning. Pedagogies: An International Journal, 4(3), 164-195.

Cowden, P. (2012). Cognitive strategies for students with mild learning disabilities. Education, 133(1), 151-154. 
Coyne, M. D., McCoach, B.D., Loftus, S., Zipoli, R., Ruby, M., Crevecoeur, Y.C., \& Kapp, S. (2010). Direct and extended vocabulary instruction in kindergarten: Investigating transfer effects. Journal of Research on Educational Effectiveness, 3(1), 93-120.

Cooper, H. (2010). Research synthesis and meta-analysis: A step-by-step approach (4th ed.). Thousand Oaks, CA: Sage.

Creswell, J. W. (2009). Research design: Qualitative, quantitative, and mixed methods approaches (3rd ed.). Los Angeles, CA: Sage.

Delpit, L. D. (1995). Other people's children: Cultural conflict in the classroom. New York, NY: The New Press.

Dorr, R. E. (2006). Something old is new again: Revisiting language experience. The Reading Teacher, 60(2), 138-146.

Eilam, B. (2012). Teaching, learning and visual literacy: The dual role of visual representation. New York, NY: Cambridge University Press.

Facella, M. A., Rampino, K. M., \& Shea, E. K. (2005). Effective teaching strategies for English language learners. Bilingual Research Journal, 29(1), 209-221.

Fiedler, C. R., Chiang, B., Van Haren, B., Jorgensen, J., Halberg, S. Boreson, L. (2008). Culturally responsive practices in schools: A checklist to address disproportionality in special education. Teaching Exceptional Children, 40(5), 52-59.

Francis, D., Rivera, M., Lesaux, N., Kieffer, M., \& Rivera, H. (2006). Practical guidelines for the education of English learners: Research-based recommendations for instruction and academic interventions. Portsmouth, $\mathrm{NH}$ : Heinemann.

Freedman, L., \& Carver, C. (2007). Preservice teacher understandings of adolescent literacy development: Naive wonder to dawning realization to intellectual rigor. Journal of Adolescent \& Adult Literacy, 50(8), 654-665.

Freire, P. (2000). Pedagogy of the oppressed. New York, NY: Continuum International.

Gandara, P., Maxwell-Jolly, J., \& Driscoll, A. (2005). Listening to teachers of English Language Learners: A survey of California teachers' challenges, experiences, and professional development needs. Retrieved from http://www.cftl.org/our_Publications.htm

Gargiulo, R. M., \& Metcalf, D. (2013). Teaching in today's inclusive classrooms: A universal design for learning approach (2nd ed.). Belmont, CA: Wadsworth Cengage Learning.

Gay, G. (2000). Culturally responsive teaching: Theory, research, and practice. New York, NY: Teachers College Press. 
Gay, G. (2002). Preparing for culturally responsive teaching. Journal of Teacher Education, 53(2), 106-116.

Gay, G. (2010). Culturally responsive teaching: Theory, research, and practice (2nd ed.). New York, NY: Teachers College Press.

Gee, J. P. (2001). Reading as situated language: A sociocognitive perspective. Journal of Adolescent and Adult Literacy, 48(8), 714-25.

Genesee, F., Lindholm-Leary, K., Saunders, W., \& Christian, D. (2005). English Language Learners in U.S. schools: An overview of research findings. Journal of Education for Students Placed at Risk, 10(1), 363-385.

Gersten, R., Baker, S., Shanahan, T., Linan-Thompson, S., Collins, P., \& Scarcella, R. (2007). Effective literacy and English language instruction for English learners in the elementary grades: A practice guide (NCEE 20074011). Washington, DC. Retrieved from http://files.eric.ed.gov/fulltext/ ED497258.pdf

Goldenberg, C. (2013). Unlocking the research on English learners: What we know and don't know yet about effective instruction. American Educator, 37(2), 4-11, 38.

Goldenberg, C., Hicks, J., \& Lit, I. (2013). Dual language learners: Effective instruction in early childhood. American Educator, 37(2), 26-29.

Greenleaf, C. L., \& Hinchman, K. (2009). Reimagining our inexperienced adolescent readers: From struggling, striving, marginalized, and reluctant to thriving. Journal of Adolescent \& Adult Literacy, 53(1), 4-13.

Guerra, S. F. (2012). Using urban fiction to engage at-risk and incarcerated youths in literacy instruction. Journal of Adolescent and Adult Literacy, 55(5), 385-394.

Hall, L. A. \& Piazza, S. V. (2008). Critically reading texts: What students do and how teachers can help. The Reading Teacher, 62(1), 32-41.

Hansen-Thomas, H., \& Cavagnetto, A. (2010). What do mainstream middle school teachers think about their English Language Learners? A tri-state case study. Bilingual Research Journal 33(1), 249-266. doi: 10.1080/152358882.2010.502803

Harste, J. C., \& Burke, C. L. (2014). Researching literate lives. In B. Kabuto \& P. Martens (Eds.), Linking families, learning, and schooling: Parentresearcher perspectives (pp. 152-68). New York, NY: Routledge.

Haynes, M. (2012). The role of language and literacy in college-and careerreadiness standards: Rethinking policy and practice in support of English language learners. Washington, DC: Alliance for Excellent Education.

Ivey, G., \& Broaddus, K. (2007). A formative experiment investigating literacy engagement among adolescent Latina/o students just beginning to read, write, and speak English. Reading Research Quarterly, 42(4), 512-545. 
Kim, A., Vaughn, S., Klingner, J. K., Woodruff, A. L., Reutebuch, C., \& Kouekanani, K. (2006). Improving the reading comprehension of middle school students with disabilities through computer-assisted collaborative strategic reading. Remedial and Special Education, 27(4), 235-249.

Klingner, J. K., \& Edwards, P. A. (2006). Cultural considerations with Responseto-Intervention models. Reading Research Quarterly, 41(1), 108-118.

Ladson-Billings, G. (2011). Is meeting the diverse needs of all students possible? Kappa Delta Pi Record, (Fall), 13-15.

Lankshear, C. (1997). Changing literacies. Philadelphia, PA: Open University Press.

Learner, J. W., \& Johns, B.H. (2015). Learning disabilities and related mild disabilities: Strategies for success (13th ed.). Stamford, CT: Cengage Learning.

Lankshear, C., \& Knobel, M. (2007). Sampling the "new" in new literacies. In M. Knobel \& C. Lankshear (Eds.), A new literacies sampler (pp. 1-24). New York, NY: Peter Lang.

Lewis, C., Enciso, P., \& Moje, E. B. (2007). Reframing sociocultural research on literacy: Identity, agency, and power. Mahwah, NJ: Erlbaum.

Lewison, M., Leland, C., \& Harste, J. C. (2014). Creating critical classrooms: Reading and writing with an edge. New York, NY: Routledge.

Lipson, M. Y., \& Wixson, K. K. (2013). Assessment of reading and writing difficulties: An interactive approach (5th ed.). Boston, MA: Pearson.

Luke, A., Woods, A., \& Dooley, K. (2011). Comprehension as social and intellectual practice: Rebuilding curriculum in low socioeconomic and cultural minority schools. Theory into Practice, 50(2), 157-164.

Mahdavi, J. N., \& Tensfeldt, L. (2013). Untangling reading comprehension strategy instruction: Assisting struggling readers in the primary grades. Preventing School Failure, 57(2), 77-92.

McIntyre, E., \& Hulan, N. (2013). Research-based, culturally responsive reading practice in elementary classrooms: A yearlong study. Literacy Research and Instruction, 52(1), 28-51.

Medina, C. (2010). "Reading across communities" in biliteracy practices: Examining translocal discourses and cultural flows in literature discussions. Reading Research Quarterly, 45(1), 40-60.

Menzies, H. M., Mahdavi, J. N., \& Lewis, J. L. (2008). Early intervention in reading. Remedial and Special Education, 29(2), 67-77.

Mercer, C. D., Mercer, A., \& Pullen, P. C. (2011). Teaching students with learning problems (8th ed.). Upper Saddle River, NJ: Pearson. 
Monroe, B., \& Troia, G. (2006). Teaching writing strategies to middle-school students with disabilities. The Journal of Educational Research, 100(1), 21-33.

Narkon, D. E., \& Wells, J. C. (2013). Improving reading comprehension for elementary students with learning disabilities: UDL enhanced story mapping. Preventing School Failure, 57(4), 231-39.

National Center for Education Statistics (2011). The Nation's Report Card: Reading 2011. (NCES 2012-457). Washington, DC: Institute of Education Sciences, U.S. Department of Education.

National Reading Panel. (2000). Teaching children to read: An evidence based assessment of the scientific research literature on reading and its implications for reading instruction (NIH Publication No. 00-4769). Retrieved from: http://www.nichd.nih.gov/publications /nrp/smallbook.htm

O'Day, J. (2009). Good instruction is good for everyone--or is it? English language learners in a balanced literacy approach. Journal of Education for Students Placed at Risk, 14(1), 97-119. doi: 10.1080/ 10824660802715502

Patel, P., \& Laud, L. (2009). Helping students to add detail and flair to their stories. Preventing School Failure, 54(1), 2-10.

Pearson, P. D., \& Gallagher, M. (1983). The instruction of reading comprehension. Contemporary Educational Psychology, 8(1), 317-344.

Perry, K. (2012). What is Literacy? A critical overview of sociocultural perspectives. Journal of Language and Literacy Education [Online], 8(1), 50-71. Retrieved from http://jolle.coe.uga.edu/wp-content/uploads/2012/ 06/What-is-Literacy_KPerry.pdf

Piazza, S. V. (2011). It's not black and white: Stories of lived experience, reading, and assessments. In Malu, K. F. (ed.), Voices in the middle: Narrative inquiry by, for, and about the middle level community (pp. 5581). Charlotte, NC: Information Age Publishing.

Roberts, G., Torgesen, J. K., Boardman, A., \& Scammacca, N., (2008). Evidence-based strategies for reading instruction of older students with learning disabilities. Learning Disabilities Research and Practice, 23(2), 63-69.

Rubinstein-Avila, E., \& Johnson, J. (2008). Meaningful content for middle school students for whom English is an additional language. In K. A. Hinchman \& H. K. Sheridan-Thomas (Eds.), Best practices in adolescent literacy instruction (pp. 20-38). New York, NY: Guilford Press.

Saunders, W., Goldenberg, C., \& Marcelletti, D. (2013). English language development: Guidelines for instruction. American Educator, 37(1), 13-25, 38. 
Short, K. G. (1996). Creating classrooms for authors and inquirers. Portsmouth, $\mathrm{NH}$ : Heinemann.

Sperling, M, Appleman, D., Gilyard, K., \& Freedman, S. (2011). Voice in the context of literacy studies. Reading Research Quarterly, 46(1), 70-84.

Street, B. (2012): Society reschooling. Reading Research Quarterly, 47(2), 216227.

Tatum, A. (2005). Teaching reading to black adolescent males: Closing the achievement gap. Portland, MN: Stenhouse Publishers.

Turnbull, A., Turnbull, R, Wehmeyer, M. L., \& Shogren, K. A. (2013). Exceptional lives: Special education in today's schools (7th ed.). Boston, MA: Pearson.

Vaughn, S., \& Edmonds, M. (2006). Reading comprehension for older readers. Intervention in School and Clinic, 41(3), 131-137.

Villegas, A. M., \& Lucas, T. (2007). The culturally responsive teacher. Educational Leadership, 64(6), 28-33.

Vygotsky, L. S. (1978). Mind in society: The development of higher psychological processes. Cambridge, MA: Harvard University Press.

Wohlwend, K. (2008). Kindergarten as nexus of practice: A mediated discourse analysis of reading, writing, play, and design in an early literacy apprenticeship. Reading Research Quarterly, 43(4), 332-334.

\section{Author Contact}

Susan V. Piazza: susan.piazza@wmich.edu

Western Michigan University, 1903 W. Michigan Ave., Kalamazoo, MI, 49008

Shaila Rao: shaila.rao@wmich.edu

Western Michigan University, 1903 W. Michigan Ave., Kalamazoo, MI, 49008

Maria Selena Protacio: selena.protacio@wmich.edu

Western Michigan University, 1903 W. Michigan Ave., Kalamazoo, MI, 49008 